Review

\title{
A Review of Tropical Plants with Antifungal Activities against Plant Fungal Pathogens
}

\section{Dewa Ngurah Suprapta}

Laboratory of Biopesticide, Faculty of Agriculture Udayana University, Jl. PB.

Sudirman, Denpasar - Bali- Indonesia; E-mail: biop@dps.centrin.net.id;

Tel./Fax: +62-361-223797

\begin{abstract}
Plant fungal pathogens are frequently found as one of limiting factors for crop production. More than 10,000 species of fungi can cause disease in plants. To control the diseases, many farmers are still rely on the use of chemical fungicides, however most synthetic fungicides can cause acute toxicity, and some cause chronic toxicity as well. Thus, an appropriate technological improvement towards a more effective use of natural resources is required in agriculture to develop environmentally friendly sustainable farming system. This paper highlights the potential of extracts of tropical plants as antifungal agent to control plant fungal diseases. Information and data presented in this paper are mainly derived from selected and related references that previously published in the scientific journals. Many higher plants of tropical origin with fungicidal activities and their potential for fungal disease control of agricultural crops have been studied, however most of the studies have been done under in vitro condition. Some plant extracts showed strong antifungal activities on in vitro as well as in vivo tests, but some plant extracts showed significant antifungal activities on in vitro test, but did not obvious on in vivo tests. A great variation in antifungal activities were shown by plants extracts of different species and plant parts, in one hand, and on the other hand, variation was also observed on the responses of different fungal species to the same plant extract. Since the purpose of the use of plant extract is to control plant fungal diseases, the field trial is needed to ensure the stability of efficacy of certain plant extract. In addition, isolation and identification of active substances in the extracts is needed to assess possible mode of action and side effect of their use.
\end{abstract}

Keywords: plant extracts; antifungal activity; fungal pathogens

\section{Introduction}

The success of crop production depends on the ability of the farmers to overcome challenges to maintain functional and profitable farms. One of the most important challenges is preventing and controlling pests and diseases problems, 
which can partly or completely ruin agricultural crops. Agricultural crops are exposed to approximately 70,000 species of pests, including pest insects, plant pathogens, and weed that potentially cause the reduction of world food production more than $40 \%$ if pesticides are not applied. Pre-harvest pest losses are approximately $40 \%$ and after harvest another $20 \%$ of the food is lost because of post-harvest pests [1]. More than 10,000 species of fungi can cause disease in plants [2]. Plant disease may be minimized by the reduction of the inoculums, inhibition of its virulence mechanisms and promotion of genetic diversity in the crop [3]. The adverse impact of plant diseases on crop production can be decreased by breeding resistant plants, good cultivation practices, or applying chemical pesticides or introducing natural enemies.

The use of chemical fungicides in agriculture has been proven to give various benefits such as reducing the fungal infection that may take water and nutrients from crop plants or may cause spoilage as the product are brought to the market. Fungicides may also prevent the growth of fungi that produce toxins, such as aflatoxins. In 1997, 5.7 billion pounds of pesticides were used worldwide, of which 0.5 billion were fungicides (Goldman, 2008). There are numerous classes of fungicides, with different modes of action as well as different potential for adverse effect on health and environment. Milne (2004) indicated 311 compounds are registered and used as fungicides to control various plant fungal diseases. Of which, seven agents are antagonistic microorganisms and only one agent is derived from plant extract (i.e. extract of Reynoutria sachalinensis (Giant Knotweed)). This plant extract is used as bioprotectant, and when sprayed on plants, the extract activates an internal defense system that prevents growth of pathogenic fungi, especially powdery mildew and grey mold.

Most fungicides can cause acute toxicity, while some cause chronic toxicity [4]. The use of chemical pesticides has been known to cause various environmental and health problems. The World Health Organization (WHO) and the United Nations Environment Programme estimate that three million workers in agriculture in developing world experience severe poisoning from pesticides, about 18,000 of whom die each year [5].

Appropriate technological improvement towards a more effective use of natural resources is required in agriculture such as the use of microbial antagonists [6] and the use of plant extracts as biocontrol agents. Higher plants of tropical origin can produce diverse anti-microbe or anti-insect substances $[7,8,9]$. Substances such as flavonoids, alkaloids and terpenoids are the secondary metabolites produced by the plants as chemical defense from pests and diseases attacks. Only $10 \%$ of the total number of plant species worldwide has been investigated for their pesticides activity. Most of the studies done under in vitro 
condition indicated that many plant extracts exhibited obvious antifungal activities against plant fungal pathogens in particular inhibited the fungal radial growth, spores formation, spores germination, and biomass formation $[10,11,12,13,14,15$, 16].

Other studies tested antifungal activities under in vitro condition followed by in vivo tests to control plant fungal diseases under green house or field condition. Extracts of 15 plant species were tested to control Ceratocystis fruit rot on Snake fruit (Salacca edulis)[10] and the result showed that the root extract of Alpinia galanga and leaf extract of Carica papaya significantly inhibited the growth of Ceratocystis sp. both on PDA medium and on Snake fruit (Salacca edulis). Leaf extract of Pometia pinnata was found to possess antifungal activity against Phytophthora infestans, effectively reduced the late blight disease on potato under field condition [17]. Application of leaf extracts of Piper betle and root extract of Alpinia galanga on banana plant in the field significantly controlled the wilt disease of banana caused by Fusarium oxysporum and Pseudomonas solanacearum [18]. Several tropical plants have been tested and proven to be effectively suppressed the growth of important fungal pathogens. The leaf extract of Piper caninum was proven to be significantly suppressed the growth of Pyricularia oryzae Cav. and significantly reduced the intensity of rice blast disease under green house condition [19]. The leaf extract of Cinnamomum burmanni showed a strong antifungal activity against Fusarium oxysforum f.sp lycopersici, and significantly reduced the incidence of Fusarium wilt disease on tomato [15] The growth of Colletotrichum acutatum, the cause of anthracnose disease on paprika was obviously inhibited by the treatment with the leaf extract of Ficus septica [16], and the formula of this extract obviously suppressed the disease intensity of anthracnose on chili pepper. This paper highlights the potential of extracts of tropical plants as antifungal agents that effectively suppress the fungal growth likewise effectively control plant fungal diseases under field condition.

\section{Tropical Plant Extracts with Antifungal Activities}

Plant extracts from several plant species such as Piper betle (Family Piperaceae), Alpinia galanga (Family Zingiberaceae), Eugenia aromatica (Family Myrtaceae), Pometia pinnata (Family Sapindaceae), Sphaeranthus indicus (Family Compositae) and Carica papaya (Family Caricaceae) were proven to posses antifungal activities on potato-dextrose agar (PDA) medium against several pathogenic fungi. Methanol extracts of A. galanga rhizome and C. papaya leaf obviously inhibited the radial growth of Ceratocystis sp., the causal agent of fruit rot disease on Salak fruit (Sallaca edulis) on PDA medium (Table 1). Treatment with $0.5 \%(\mathrm{w} / \mathrm{v})$ extracts of $A$. galanga or C. papaya inhibited the radial growth of 
Ceratocystis sp. by $92.5 \%$ and $73.3 \%$ respectively. On the test done on pulp-cuts showed that the growth of Ceratocystis sp. was obviously inhibited by the treatment with extract of either ginger root or papaw leaves. A similar result was found on Salak fruit that artificially inoculated with spores of Ceratocystis sp. The fruits which previously treated with plant extracts of ginger root or papaw leaves prior to inoculation showed no symptom of Ceratocystis fruit rot up to 7 days while all $(100 \%)$ of untreated fruit have rotten 4 days after inoculation. Under natural condition (without artificial inoculation), the shelf-life of the snake fruit could be extended up to 10 days at room temperature when they were treated with extracts of either ginger root or papaya leaves [10]. Other plants have been studied for their antifungal activities in vitro against Fusarium guttiforme and Chalara paradoxa [20], Pyricularia oryzae [11], Botrytis cinerea [12], Glomerella cingulata [13], Fusarium oxysforum [14].

Fifty six plant species were tested for their antifungal activities against Fusarium guttiforme and Chalara paradoxa, fungal pathogens of pineapple [20]. Two plant species viz. Bonnetia stricta and Ginkgo biloba showed strong antifungal activities against $C$. paradoxa with diameter of inhibition zones of 25 and $20 \mathrm{~mm}$ respectively. Three plant species viz. Aloe sativum, Ginkgo glabra and Kielmeyera membranacea resulted in strong antifungal activities against F. guttiforme with diameter of inhibition zones of 25, 24, and $26 \mathrm{~mm}$ respectively. Extracts of six plant species namely Ocinum gratissimum, Chromolaena odorata, Cymbopogon citratus, Eugenia aromatica, Piper guineense and Garcinia kola showed significant suppression to the sporulation and mycelia growth of Pyricularia oryzae [11].

Extract of Hyssopus officinalis at concentration of $5 \%$ completely $(100 \%)$ inhibited the growth of Botrytis cinerea, the cause of grey mold of more than 230 plant species [12], while on the other study the extract of Coriandrum sativum strongly inhibited the growth of Glomerella cingulata with inhibitory activity by $92.81 \%$ [13]. Conidia germination and mycelia growth of Fusarium oxysforum significantly suppressed by the treatment of extracts of 11 different species [14]. Among them, five plant species namely Rivina humulis, Brassica carinata, Brunfelsia calyicina, Salvia guaranitica, and Punica granatum showed good antifungal activity. Leaf extract of Cinnamomum burmanni at concentration of 1.0 to $2.0 \%$ $(\mathrm{w} / \mathrm{v})$ effectively suppressed radial growth, biomass formation, and spores formation of Fusarium oxysforum f.sp. lycopersici, the cause of Fusarium wilt disease on tomato [15]. Other study showed that the leaf extract of Piper caninum at concentration of 0.5 to $3.5 \%$ $(\mathrm{w} / \mathrm{v})$ significantly suppressed radial growth, spores formation and biomass formation of Pyricularia oryzae the cause of rice blast disease [19] 
Table 1. List of plants tested for their antifungal activities against Ceratocystis sp. the cause of fruit rot disease on snake fruit (Salacca edulis)

\begin{tabular}{|l|l|l|c|}
\hline No. & \multicolumn{1}{|c|}{ Scientific name/Plant part } & \multicolumn{1}{c|}{ Family } & $\begin{array}{c}\text { Inhibitory activity } \\
(\%)\end{array}$ \\
\hline 1 & Plumeria acuminate/leaves & Apocynaceae & 6.8 \\
\hline 2 & Sambucus javanica/leaves & Capripoliaceae & 25.4 \\
\hline 3 & Eclipta alba/leaves & Compositae & 18.7 \\
\hline 4 & Cajanus cajan/seed & Papilionaceae & 8.9 \\
\hline 5 & Alpinia galanga/rhizome & Zingiberaceae & 92.5 \\
\hline 6 & Carica papaya/leaves & Caricaceae & 73.3 \\
\hline 7 & Piper nigrum/leaves & Piperaceae & 21.2 \\
\hline 8 & Piper betle/leaves & Piperaceae & 38.4 \\
\hline 9 & Piper refractrum/fruit & Piperaceae & 42.8 \\
\hline 10 & Azadirachta indica/leaves & Meliaceae & 12.7 \\
\hline 11 & Caesalpinia pulcherima/leaves & Caesalpeniaceae & 8.7 \\
\hline 12 & Euphorbia tirucalli/stem & Euphorbiaceae & 38.5 \\
\hline 13 & Andrographis paniculata/leaves & Acanthaceae & 45.8 \\
\hline 14 & Allium cepa/bulb & Liliaceae & 41.5 \\
\hline 15 & Allium ascalonicum/bulb & Liliaceae & 22.8 \\
\hline
\end{tabular}

Source : [10]

Three plant species namely Vernonia polysphaera, Syzygium aromaticum, and Allium sativum effectively inhibited the mycelia growth and conidial germination of Cercospora coffeicola, Colletotrichum gloeosporioides, Fusarium oxysforum, Phoma tarda, Rhizoctonia solani, and Hemileia vastatrix [21]. Ethanol and acetone extract of leaves of nine medicinal plants namely Piper betel, Lowsonia inermis, Psidium guajava, Carica papaya, Moringa oleifera, Mimosa pudica, Cathanthus roseus, Adhatoda vasica, and Andrographis paniculata were tested for their inhibitory activities against Fusarium oxysforum the causal agent of Fusarium wilt in tomato [22]. Among them, ethanol extracts of two plants viz. Lowsonia inermis, and Psidium guajava showed superior inhibitory activity $(100 \%)$ at concentration $15 \%$.

A great variation in antifungal activities were shown by plants extracts of different species and plant parts, and on the other hand, variation was also observed on the responses of different fungal species to the same plant extract as shown in Table 2. This is probably due to the variation in type and concentration of antifungal substances in different plant species and plant parts. Different responses of different fungi to the same extract indicated genetic diversity among plant fungal pathogens. 
Tabel 2. Variation in antifungal activities of different plants and variation of fungal responses against the same plant extract

\begin{tabular}{|c|c|c|c|c|c|}
\hline No. & Plant species & $\begin{array}{l}\text { Plant } \\
\text { parts }\end{array}$ & $\begin{array}{l}\text { Fungal } \\
\text { pathogens }\end{array}$ & $\begin{array}{l}\text { Inhibitory } \\
\text { activity } \\
(\%)\end{array}$ & References \\
\hline 1 & Ficus septica & Leaves & $\begin{array}{l}\text { Colletotrichum } \\
\text { acutatum }\end{array}$ & 99.11 & [16] \\
\hline 2 & Piper caninum & Leaves & $\begin{array}{l}\text { Pyricularia } \\
\text { oryzae }\end{array}$ & 95.8 & [19] \\
\hline 3 & $\begin{array}{l}\text { Cinnamomum } \\
\text { burmanni }\end{array}$ & Leaves & $\begin{array}{l}\text { Fusarium } \\
\text { oxysforum f.sp. } \\
\text { lycopersici }\end{array}$ & 93.71 & [15] \\
\hline 4 & Eugenia aromatica & Seeds & $\begin{array}{l}\text { Pyricularia } \\
\text { oryzae }\end{array}$ & 100 & {$[11]$} \\
\hline 5 & Hyssopus officinalis & $\begin{array}{l}\text { Stems, } \\
\text { leaves }\end{array}$ & Botrytis cinerea & 100 & [12] \\
\hline 6 & Coriandrum sativum & $\begin{array}{l}\text { Aerial } \\
\text { parts }\end{array}$ & $\begin{array}{l}\text { 1.Botryotina } \\
\text { fuckeliana } \\
\text { 2. Glomerella } \\
\text { cingulata } \\
\text { 3. Fusarium } \\
\text { oxysforum } \\
\text { 4. Pectobacterium } \\
\text { Carotovorum } \\
\text { subsp. } \\
\text { carotovorum }\end{array}$ & $\begin{array}{c}100 \\
92.21 \\
29.41 \\
40.94\end{array}$ & [13] \\
\hline 7 & $\begin{array}{l}\text { 1. Punica granatum } \\
\text { 2. Salvia guaranitica } \\
\text { 3. Allium triquetrum } \\
\text { 4. Campsis radicans }\end{array}$ & $\begin{array}{l}\text { Peel } \\
\text { Leaf } \\
\text { Leaf } \\
\text { Leaf }\end{array}$ & $\begin{array}{l}\text { Fusarium } \\
\text { oxysforum f.sp. } \\
\text { lycopersici }\end{array}$ & $\begin{array}{lr}\text { 1. } & 100 \\
\text { 2. } & 100 \\
\text { 3. } & 95.0 \\
\text { 4. } & 6.0\end{array}$ & {$[14]$} \\
\hline
\end{tabular}

Plant Extracts as Fungal Diseases Control Agent

Several evidences showed that plant extracts of tropical origin effectively controlled the plant fungal diseases under in vivo and field condition $[6,9,15,16$, $18,19,20,23,24,25,26,27,28,29,30]$. Suprapta et al. (2001) tested extracts of 15 
plant species to control Ceratocystis fruit rot on snake fruit (Salacca edulis) and found.The root extract of Alpinia galanga and leaf extract of Carica papaya effectively reduced the incidence of fruit rot disease on snake fruit caused by Ceratocystis sp. [10].

Leaf extract of Pometia pinnata was found effectively reduced the intensity of late blight disease on potato under field condition [17]. Application of leaf extracts of Piper betle and root extract of Alpinia galanga on banana plant in the field significantly suppressed the wilt disease of banana caused by Fusarium oxysporum and Pseudomonas solanacearum [18]. Formula of the leaf extract of Piper caninum at concentration $2.5 \%(\mathrm{v} / \mathrm{v})$ reduced the intensity of rice blast disease by $90.51 \%$ under green house condition [19]. The leaf extract of Cinnamomum burmanni showed a strong antifungal activity against Fusarium oxysforum f.sp lycopersici, and and the formula of this extract at concentration $2 \%(\mathrm{v} / \mathrm{v})$ reduced the incidence of Fusarium wilt disease on tomato grown in a green house by $80.95 \%$ when compared with control [15]. The growth of Colletotrichum acutatum, the cause of anthracnose disease on paprika was obviously inhibited by the treatment with the leaf extract of Ficus septica [16], and the formula of this extract at concentration $4 \%(\mathrm{v} / \mathrm{v})$ suppressed the disease intensity of anthracnose by $95.55 \%$ on chili pepper grown in a green house.

Antifungal activities of extracts of $P$. betle leaf and A. galanga, alone or in a mixture were tested to control the wilt disease on banana seedling caused by Fusarium oxysporum f.sp. cubense [23]. Extract treatment was done by soaking the corm cuttings derived from corms of diseased-banana trees. Only few seedlings on control were found to be healthy, while most of the seedlings treated with plant extracts were healthy. The use of these plant extracts even gave better results than that of chlorothalonil, a synthetic fungicide [23] as shown in Table 3.

Table 3. Percent healthy seedlings resulting from banana corm with or without plant extracts treatment

\begin{tabular}{|l|c|c|c|}
\hline \multirow{2}{*}{\multicolumn{1}{|c|}{ Treatment }} & \multicolumn{3}{c|}{ Percent of healthy seedling } \\
\cline { 2 - 4 } & Experiment 1 & Experiment 2 & Experiment 3 \\
\hline Control & $18.8 \mathrm{a}$ & $11.9 \mathrm{a}$ & $10.1 \mathrm{a}$ \\
\hline Extract of Piper betle & $89.6 \mathrm{~d}$ & $92.7 \mathrm{c}$ & $84.1 \mathrm{bc}$ \\
\hline Extract of Alpinia galanga & $86.4 \mathrm{c}$ & $89.6 \mathrm{c}$ & $85.9 \mathrm{c}$ \\
\hline P. betle and A. galanga & $93.2 \mathrm{e}$ & $92.9 \mathrm{c}$ & $90.2 \mathrm{~d}$ \\
\hline Chlorothalonil & $77.0 \mathrm{~b}$ & $80.1 \mathrm{~b}$ & $81.4 \mathrm{~b}$ \\
\hline
\end{tabular}

Source : [23].

Application of extract of Alpinia galanga by soaking stem-cuttings of 
vanilla and followed by soil dressing three, six and nine days after planting obviously reduced the stem rot disease incidence on vanilla seedlings [24]. Treatments with plant extract at concentration $0.3 \%$ and $0.5 \%$ reduced the disease incidence by $47.1 \%$ and $98.6 \%$ respectively. Suprapta and Ohsawa [25] proved that the leaf extract of Piper betle at concentration of $0.3 \%(\mathrm{w} / \mathrm{v})$ applied as soil dressing into the soil that previously inoculated with Fusarium oxysporum f.sp. vanillae completely could protect the vanilla seedlings from infection, while all seedlings of control showed severe stem rot disease. Aqueous extract of Echinops sp. at concentration $25 \%(\mathrm{w} / \mathrm{v})$ significantly reduced the incidence and severity of anthracnose disease on papaya fruit caused by Colletotrichum gloeosporioides [27]. This treatment produced the highest marketable papaya fruit and comparable to the synthetic fungicide, Carbendazim. Other study done by Cosoveanu [28] indicated that the essential oil of Artemisia absinthium was very effective in reducing disease severity of apple fruit infected with Penicillium expansum applied as curative treatment. Bahraminejad [29] tested Iranian plant species to control root rot disease on cucumber caused by Pythium aphanidermatum and showed that the extracts of Glycyrrhiza glabra and Portulaca oleraceae obviously reduced the disease severity.

A formula containing a mixture of $5 \%(\mathrm{w} / \mathrm{v})$ buds extract of Eugenia aromatica and $5 \%(\mathrm{w} / \mathrm{v})$ leaves extract of Piper betle was tested under filed condition to control black pod disease on cocoa caused by Phytophthora palmivora. The results showed that treatment with this formula reduced the incidence of black pod disease by $68 \%$ when compared with control and comparable to the treatment with synthetic fungicide, Dithane-M45 [26]. The efficacy of plant extracts under field condition was also proven by Arya et al. [31]. Two applications of 500-ml water extract of Piper betle with one month interval at a concentration of $5 \%(\mathrm{w} / \mathrm{v})$ significantly reduced the wilt disease incidence on banana caused by Fusarium oxysporum f.sp. cubense. Study done by Suprapta et al. [17] showed that application of leaves extract of Pometia pinnata on potato plant under field conditions obviously inhibited the development of the late blight disease caused by Phytophthora infestans, which is comparable to the synthetic fungicide, Chlorotalonil.

The above mentioned evidences suggested that several plants of tropical areas potentially can be used as fungal disease control agent under field condition. Some of them showed comparable effectiveness with synthetic fungicides. The use of plant extract may give better result when it is combined with other cultural practice. As suggested by Ventiborgh [32], pod losses caused by Phytophthora megakarya in Cameroon were reduced from $35 \%$ to about $1 \%$ by combining sanitation practices with fungicides application. Opuku et al. [33] also reported that the incidence of black pod disease in Ghana could be effectively controlled by 
a combination of fungicide application and sanitation practices. This treatment resulted in $25 \%$ to $48 \%$ diseases reduction and $11 \%$ to $51 \%$ yield increase.

The future challenges are to find efficient extraction method, formula development as well as application method that can consistently maintain the efficacy of the extract under in vivo or field condition. In addition, the isolation and identification of the active substances responsible for the antifungal activity is needed in order to predict the possible mode of action and side effects of their use.

Several reports described the substances in the plant extracts related to the antifungal activity. Saponins are known as potent antifungal substances, which occur in high concentration in healthy higher plants and contribute to the resistance of plant against fungal infection [34]. Rhizome of Alpinia galanga contains several essential oils such as cineol, eugenol, galangin, galangol, pinen, camphor and methylcinamate that probably related to antifungal activity [35]. Dadang [36] found that A. galanga contains 1-acetoxychavicol acetate that may serves as antifungal substance. Several substances were identified and were thought to be responsible for the antifungal activity, namely 3-(4-hydroxyphenyl)-2(E)-propenoate isolated from Costus specious [37]; isobutyric acid, butyric acid, valeric acid and caproic acid from Portulaca oleracea [38]; Tiliacorine from Tiliacora racemosa [39]; Guaianolides from Chichorium intybus [40]; acetoxychavidol acetate from Alpinia galanga [41]. Eight substances in the leaves extract of Ficus septic were found to serve as antifungal against Colletotrichum acutatum namely heptanes 2,3,5 trimethyl, sulfurous acid cyclohexylmethyl hexadecyl ester, dodecanoic acid methyl ester, 3-deoxy-d-mannoic acid, hexadecanoic acid methyl ester, octadecamethyl cyclonanosiloxane, 1-heptacosanol, and 1,2 benzenedicarboxylic acid mono (2-etilhexyl) [16]. Other researcher found six compounds in the leaves extract of Piper caninum that serve as antifungal against Pyricularia oryzae the cause of rice blast disease [42]. Those compounds are benzene, tetradecane, dodecanoic acid, hexadecanoic acid, octadecamethylcyclonanosiloxane, and 1,2-benzenedicarboxylic acid.

The essential oil of Eugenia aromatica contained 87\% eugenol, 8.01\% eugenyl acetate and $3.56 \%$ beta caryophyllene [43]. A study done by Nalina and Rahim [44] showed that the extract of Piper betle contained hydroxychavicol, fatty acids (stearic and palmitic) and hydroxyl fatty acid esters (stearic, palmitic and myristic). The important constituents of essential oil of $P$. betle are the phenols, eugenol, chavicol, methyl chavicol and betelphenol [45]. The leaf extract of this plant has antibacterial and antifungal activity, and the antifungal activity has been related to the presence of eugenol [45]. 


\section{Conclusions}

Many extracts of tropical plants have been investigated for their antifungal activities, both under in vitro and in vivo condition. Most of the researchers did in vitro tests, while others did both in vitro and in vivo test. Since the main purpose of the use of plant extract is to control plant fungal diseases, the tests under green house and field condition is needed to ensure the stability and consistency of the efficacy of the extract. Some extracts showed strong antifungal activities on in vitro test, but did not show obvious result when they are applied in the field. To overcome this gap, it is suggested to conduct the in vitro test followed by the field test. The use of plant extract alone may give no satisfied result, but when it is combined with other measure may give better control level against fungal diseases. Isolation and identification of active compounds in the plant extract that responsible for antifungal activity is needed, in order to assess the efficacy, mode of action and possible side effects of their use. In addition, formula development is important step to get economical and effective use of plant extract as fungal diseases control agent.

\section{References}

1. Pimentel, D. Techniques for reducing pesticide use. Economic and environmental benefit. John Wiley \& Sons, Chichester, UK. 1997, pp. 51-78.

2. Agrios, G.N. Plant Pathology. Fifth Edition. Elsevier Academic Press, London, UK, 2005; 922 p.

3. Strange, R.N.; Scott, P.R. Plant Disease : A Threat to Global Food Security. Ann. Rev. Phytopathology, 2005, 43, 83-165.

4. Goldman, L.R. Encyclopedia of Public Health: Fungicides, 2008. Cited on 6 June 2016, available from http://www.answers.com/topic/fungicide?cat=technology

5. Miller, G.T. Sustaining the Earth, $6^{\text {th }}$ Edition. Thompson Learning, Inc. Pacific Grove California, Chapter 9, 2004, pp. 211-216.

6. Suprapta, D.N. Potential of microbial antagonists as biocontrol agents against plant fungal pathogens. J. ISSAAS., 2012, 18, 1-8.

7. Downum, K.R.; $\quad$ Romeo, J.T.; Sataford, H.A. (Eds). Phytochemical potential of tropical plants. Plenum Press. New York, 1993, 299 p.

8. Lis-Balchin, M.; Dean, S.; Hart, S. Bioactivity of Newzealand medicinal plant essential oils. Acta Horticulturae, 1996,426,13-29.

9. Nakamura, Y.K.; T. Matsuo; Shimoi, K.; Nakamura, Y. Methyl methanethiosulfonate in homogenates of Cruciferae and Liliaceae vegetables. Bio. Biotech. Biochem., 1996, 60,1439-1443.

10. Suprapta, D.N.; Sudana, I.M.; Arya, N. Application of plant extracts to control Ceratocystis fruit rot in snake fruit (Salacca edulis). J. ISSAAS., 2001, 7: 10-16. 
11. Olufolaji, D.B.; Adeosum, B.O.; Onasanya, R.O. In vitro investigation on antifungal activity of some plant extracts against Pyricularia oryzae. Nigerian J. Biotech., 2015, 29, 38-43.

12. Sesan, T.E.; Enache, E.; Iacomi, B.M. (2015). Antifungal activity of some plant extracts against Botrytis cinerea Pers. In the Blackcurrant Crop (Ribes nigrum L.). Acta Scientiarum Polonorum, Hortorum Cultus, 2015, 14: 29-43.

13. Ikeura, H.; Kobayashi, F. Antimicrobial and antifungal activity of volatile extracts of 10 herb specie against Glomerella cingulata. J. Agric. Sci., 2015, 7, 77-84.

14. Rongai, D.; Pulcini, P.; Pesce, B.; Milano, F. Antifungal activity of some botanical extracts on Fusarium oxysforum. Open Life Sci., 2015, 10, 409-416.

15. Darmadi, A.A.K.; Suprapta, D.N.; Temaja, I.G.R.M.; Sudana, I.M. (2015).

Leaf extract of Cinnamomum burmanni Blume effectively suppress the growth of

Fusarium oxysforum f.sp. lyciopersici the cause of Fusarium wilt disease on

tomato. J. Bio. Agric. Healthcare, 2015, 5, 131-137.

16. Sudirga, S.K., Suprapta, D.N., Sudana, I.M.,\& Wirya, I.G.N.A.S. Antifungal activity of leaf extract of Ficus septica against Colletotrichum acutatum the cause of anthracnose disease on chili pepper. J. Bio. Agric. Healthcare, 2014, 4, 47-52.

17. Suprapta, D.N.; Swari, I.G.A.N.A.; Arya, N. Pometia pinnata leaves extracts to control late blight disease in potato. J. ISSAAS., 2002, 8, 31-36.

18. Arya, N.; Suprapta, D.N.; Maya Temaja, G.R.; Suyama, K. Evaluation of six bacterial antagonists to control tomato wilt disease. J. ISSAAS, 2002, 2, 15-21.

19. Suriani, N.L.; Suprapta, D.N.; Sudana, M.; Temaja, I.G.R.M. Antifungal activity of Piper caninum against Pyricularia oryzae Cav. the cause of rice blast disease on rice. J. Bio. Agric. Healthcare, 2015, 5, 72-78.

20. Sales, M.D.C.; Costa, H.B.; Fernandes, P.M.B.; Ventura, J.A.; Meira, D.D. Antifungal activity of plant extract with potential to control plant pathogens in pineapple. Asian Pacific J. Trop. Biomed., 2016, 6, 26-31.

21. Silva, J.L.; Souza, P.E.; Monteiro, F.P.; Freitas, M.L.O.; Silvia, M.B. Jr.; Belan, L.L. (2014). Antifungal activity using medicinal plant extracts against pathogens of coffee tree. Rev. Bra. Pl. Med., Campinas, 2014, 16, 539-544.

22. Neela, F.A.; Sonia, I.A.; Shamsi, S. Antifungal activity of selected medicinal plant extract on Fusarium oxysforum Schechtthe causal agent of Fusarium wilt disease in Tomato. American J. Plant Sci., 2014, 5, 2665-2671.

23. Suprapta, D.N.; Sudarma, M.; Arya, N.; Ohsawa, K. Plant extracts to control wilt disease in banana seedlings. J. ISSAAS., 2005a, 11:84-90.

24. Suprapta, D.N.; Sudarma, M.; Ohsawa, K. Fungicidal activity of Alpinia galanga extract against Fusarium oxysporum f.sp. vanillae, the causal agent of stem rot disease on vanilla. J. ISSAAS., 2005b, 11, 150-155.

25. Suprapta, D.N.; Ohsawa, K. Fungicidal activity of Piper betle extract against Fusarium oxysporum f.sp. vanilla. J.ISSAAS., 2007, 13, 40-46. 
26. Suprapta, D.N.; Sudana, M.; Wirya, G.N.A.S.; Sudiarta, P. Plant extracts to control cocoa black pod disease caused by Phytophthora palmivora. J. ISSAAS., 2008, 13, 22-30.

27. Ademe, A.; Ayale, A.; Woldetsadik, K. Evaluation of antifungal activity of plant extracts against papaya anthracnose (Colletotrichum gloeosporioides). J. Plant Pathol. Microbiol. 2013, 4, 207. Doi:10.4172/2157-7471.1000207.

28. Cosoveanu, A.; Cabrera,R.; Marino, C.G.; Iacomi, B.M.; Gonzales-Coloma, A. (2013). Antifungal activity of plant extracts against pre and postharvest pathogens. Agronomy, 2013, 56, 206-211.

29. Bahraminejad, S. (2012). In vitro and in vivo antifungal activity of Iranian plant species against Pythium aphanidermatum. Ann. Bio. Res., 2012, 3, 2134-2143.

30. Bajpai, V.K.; Kang, S.C. In vitro and in vivo inhibition of plant pathogenic fungi by essential oil and extracts of Magnolia liliflora Sesr. J. Agric. Sci. Tech., 2012, 14, 845-856

31. Arya, N.; Suprapta, D.N.; Sudana, M. Introduction of biopesticide to control banana wilt disease. J. ISSAAS, 2001, 7, 1-9.

32. Ventiborgh, L. Integrated control of black pod disease of cocoa in Cameroon. Parasitica, 1987, 43:49-60.

33. Opuku, I.Y.; Assuah, M.K.; Aneani, F. Management of black pod disease of cocoa with reduced number of fungicide application and crop sanitation. African J. Agric. Res. 2007, 2,601-604.

34. Osbourn, A.E. Saponins and plant defence- A soap story. Trend Plant Sci., 1996, 1,4-9.

35. Anonymous. 1986. Medicinal herb index in Indonesia. PT. EISAI. Jakarta, 1986, 114 p.

36. Dadang. Insect regulatory activity and active substances of Indonesian plants particularly to the diamondback moth. Dissertation. Department of Bioregulation Studies, Graduate School of Agriculture, Tokyo University of Agriculture, Tokyo. $1999,179 \mathrm{p}$.

37. Bandara, B.M.R.; Kumar, N.S.; Samaranayake, K.M.S. An antifungal constituent from the stem bark of Butea monosperma. J. Ethnopharm, 1989, 25,73-75.

38. Park, J.S.; Nishimura, S.; Marumo, S.; Katayama, M. Isolation and identification of antifungal fatty acids from the extract of Portulaca oleracea L". Korean J. Plant Pathol, 1986, 2,82-88.

39. Tripathi, Y.C.; Dwivedi, R.K.(1989). Antifungal activity of alkaloids of Tiliacora racemosa. Nat. Acad. Sci. Letters, 1989,12:69-71.

40. Mares, D.; Romagnoli, C.; Tosi, B.; Andreotti, E.; Chillemi, G.; Poli, F. Chicory extracts from Cichorum intybus L. As potential antifungal. Mycopathologia, 2005, 160,85-92.

41. Janssen, A.M.; Scheffer, J.J. Acetoxychavicol acetate an antifungal component of Alpinia galangal. Planta Med., 1985, 6,507-511.

42. Suriani, N.L. Use of leaves extract of Piper caninum Blume to control Pyricularia oryzae Cav. the cause of blast disease in rice. Dissertation. School of Posgraduate Udayana University, Denpasar Bali. 2015, $104 \mathrm{p}$.

43. Alma, M.H.; Ertas, M.; Nitz, S.; Kollmannsberger, H. Chemical composition 
and content of essential oil from the bud of cultivated Turkish Clove (Syzygium aromaticum L.). BioResources, 2007, 2, 265-269.

44. Nalina, T.,\& Rahim, Z.H.A. The crude aqueous extract of Piper betle L. and its antibacterial effect towards Streptococcus mutans. American J. Biotech. Biochem. 2007, 3, 10-15.

45. Van der Vossen, H.A.M.; Wessel, M. (eds.). (2000). Plant resources of South-east Asia No.16. Stimulant. Backhuys Publishers, Leiden, the Netherlands. 2000, 201 p.

(C) 2016 by the author; licensee Preprints, Basel, Switzerland. This article is an open access article distributed under the terms and conditions of the Creative Commons by Attribution (CC-BY) license (http://creativecommons.org/licenses/by/4.0/). 